physician's assessment of ulcers, 7/patient's evaluation of changes in ulcers, 8/ physician's evaluation of changes in ulcers $9 /$ number of digital ulcers.

The patients were evaluated after the drug infusion and 1 year later. Clinical and demographic characteristics of patients treated with vasoactive drugs are presented in table 1.

Results: Table 1. Clinical and demographic characteristics of patients with digital ulcers

\begin{tabular}{lcc}
\hline & Ilomedin $^{\circledast}$ & Vazaprostan $^{\oplus}$ \\
\hline $\mathrm{N}$ & 22 & 20 \\
Females (\%) & 100 & 90 \\
Age & $46.7( \pm 9.9)$ & $41.9( \pm 12.9)$ \\
Diffuse SSc (\%) & 36.4 & 14.3 \\
SSc duration (yy) & 12.9 & 10.8 \\
$\mathrm{~N}$ of ulcers (baseline) & $3.3( \pm 2.2)$ & $1.7( \pm 1.03)$ \\
\hline${ }^{*}$
\end{tabular}

${ }^{*}$ Mean \pm SD

Results: The results obtained show improvement of ischaemic lesions in both groups.

The comparison of results speaks in favour of Vasoprostan vs llomedin in terms of significant pain reduction, table 2 .

Abstract SAT0503 - Table 2. Comparative characteristics of scores and values from different assessment tools in groups treated with Vasoprostan and llomedin (post-treatment).

\begin{tabular}{lcc}
\hline & Ilomedin $^{\oplus}$ & Vazaprostan $^{\oplus}$ \\
\hline HAQ-SSc & 1.49 & 1.18 \\
HAQ & 1.22 & 1.18 \\
Cochin score & 16.38 & 22 \\
VAS & $46.61^{*}$ & $27.12^{*}$ \\
Physicians Global assessment & 3.8 & 3.5 \\
patients Global assessment & 4.61 & 3.75 \\
Ulcers N & 3.07 & 1.16 \\
\hline${ }^{*}$ P 0.05 & &
\end{tabular}

Conclusions: It should be noted that certain degree of positive dynamics in healing of ulcers was established by practically all assessment tools. VAS looks like the most sensitive tool in evaluation of pain. Of importance is the fact, that despite marked ischaemic lesions and digital ulcers, the Cochin score reflecting hand functional capacity did not exceed average values at baseline and did not change significantly post-treatment.

Disclosure of Interest: None declared

DOI: 10.1136/annrheumdis-2018-eular.5079

\section{SAT0504 THE ASSOCIATION OF MYOSITIS SPECIFIC ANTIBODIES IN PATIENTS WITH INFLAMMATORY MYOSITIS: PRELIMINARY DATA IN INDIAN PATIENTS}

N.V. Negalur ${ }^{1}$, D. Raval ${ }^{1}$, M. Bindroo ${ }^{1}$, W. Kazi ${ }^{1}$, U. Baveja ${ }^{2}$, R. Gupta ${ }^{1}$.

${ }^{1}$ Rheumatology and Clinical Immunology, ${ }^{2}$ Microbiology, MEDANTA- THE MEDICITY, Gurgaon, India

Background: Studies in Autoimmune Inflammatory Myositis (AIM) have shown that certain antibodies have a role in the diagnosis and prognosis of patients with myositis. This ongoing study presents the preliminary data of 48 patients of Indian AIM.
Objectives: To study the prevalence of Myositis specific and Myositis Associated antibodies (MSA and MAA respectively) in Indian patients with AIM and to correlate these antibodies with clinical features.

Methods: All consecutive patients with Inflammatory myositis (satisfying the Bohan and Peter criteria, 1975 attending the Rheumatology and Clinical Immunology department of Medanta hospital from November 2016 to October 2017 were included prospectively and divided into groups as Dermatomyositis (DM), Poly myositis (PM), CTD associated myositis (CTD-M), Cancer associated myositis (CAM) and Juvenile Myositis (JM). Their clinical data and sera were collected after obtaining informed consent. Sera was analysed for IgG antibodies against Jo-1, PL-7, PL-12, EJ, SRP, Mi-2, MDA-5, TIF1 $\gamma$, SAE1, SAE2, NXP2 and SSA/ R052kD using the microELISA technique (BlueDriver Dot Myositis ${ }^{12}$ SAE IgG kit). Their ENA was also recorded (Blue DriverQuantrix-ANA25 Screen IgG kit d-tek) Results were read by the BlueScan scanner and value $\geq 10$ were considered positive. The study was approved by the Ethics committee of Medanta hospital.

Results: There were 48 patients in the cohort $(M: F=12: 36)$ with the mean age of 41.3 years and a median disease duration of 30 months. Nineteen of them were DM, 19 were PM, 5 were CTD-M, 2 were CAM and 3 were JM. 58.3\% were ANA positive and MSA were positive in $37.5 \%$ of the cohort, MSA being mutually exclusive. Antibodies against Mi-2 were present in 6 patients (12.5\%), Jo-1 antibodies in $5(10.4 \%), 2$ (4.1\%) patients each had PL-7 and SRP antibodies. One patient $(2 \%)$ each had MDA-5, NXP2 and TIf $1 \gamma$ antibodies. MAAs were seen in $39.5 \%$ of the cohort with antibodies against Ro, RNP and PM- Scl seen in 16 (33.3\%), 2 $(4.1 \%)$ and $1(2 \%)$ respectively. Mi-2 antibodies were seen only in DM and JM group. The lone patient who had MDA-5 antibody had amyopathic DM. Malig nancy screening was negative in NXP2 and TIF1 $\gamma$ antibody positive patients.

Conclusions: MSA were present in almost $40 \%$ of the cohort. Mi-2 antibodies were associated with rash and none had ILD whereas Jo-1 antibodies were associated with mechanic hands, arthritis and ILD. With further recruitment of patients in this ongoing study, we hope to get more robust data in future.

Disclosure of Interest: None declared

DOI: 10.1136/annrheumdis-2018-eular.1867

\section{SAT0505 COMPARISON OF LONG-TERM CYCLOPHOSPHAMIDE (CY) AND MYCOPHENOLATE MOFETIL (MMF) EFFICACY AND SAFETY IN PATIENTS WITH SYSTEMIC SCLEROSIS (SSC) AND INTERSTITIAL LUNG DISEASE (ILD)}

O. Koneva, O. Ovsyannikova, O. Desiniva, L. Garzanova, L. Ananieva,

M. Starovoytova. Nasonova Research Institute of Rheumatology, Moscow, Russian Federation

Background: CY is considered to be the drug of choice for ILD therapy in patients with SSc. However, based on published evidence, only temporary and modest improvement of pulmonary fibrosis is usually achieved, therefore search for new more effective and safe agents is ongoing, with specific attention given to MMF. Objectives: To compare CY and MMF effects on SSc clinical manifestations and activity, and safety of both agents in an open prospective non-randomised study. Methods: The study included patients with a documented SSc diagnosis and ILD signs based on HRCT data. All patients were treated with immunosuppressants in combination with low and medium doses of glucocorticoids. 36 pts (mean age 47 \pm 12 years, $\mathrm{m} / \mathrm{f} 1 / 1,1$, SSc duration $5.0 \pm 4.8$ years, diffuse/limited $-1 / 1,6$ ) were administered parenteral $C Y$ during $12 \pm 6$ months, with a cumulative dose of 10.6 \pm 5 g. 45 pts (mean age $49 \pm 13$ years, $m / f-1 / 10$, SSc duration $7.6 \pm 6.3$ years, diffuse/limited $-1 / 1,3$ ) were administered MMF at $2 \mathrm{~g} /$ day during $13 \pm 2$ months. The

Abstract SAT0504 - Table 1. Myositis Antibody distribution according to clinical features.

\begin{tabular}{|c|c|c|c|c|c|c|c|c|c|}
\hline & $\begin{array}{c}\text { Proximal muscle } \\
\text { weakness }(\%)(n=46)\end{array}$ & $\begin{array}{c}\text { Pharyngeal muscle } \\
\text { weakness (\%) }(n=17)\end{array}$ & $\begin{array}{c}\text { Rash (\%) } \\
(\mathrm{n}=28)\end{array}$ & $\begin{array}{l}\text { Mechanic hands } \\
(\%)(n=5)\end{array}$ & $\begin{array}{c}\text { Raynaud's (\%) } \\
(n=11)\end{array}$ & $\begin{array}{l}\text { Digital Ulcer } \\
(\%)(n=2)\end{array}$ & $\begin{array}{c}\text { Arthritis (\%) } \\
(n=13)\end{array}$ & $\begin{array}{c}\text { ILD (\%) } \\
(n=11)\end{array}$ & $\begin{array}{c}\text { Total } \\
(\mathrm{n}=48)\end{array}$ \\
\hline \multicolumn{10}{|c|}{ Myositis Specific Antibodies } \\
\hline MI-2 & $6(13)$ & $2(11.7)$ & $6(21.4)$ & 0 & $1(9)$ & 0 & $1(7.6)$ & 0 & $6(12.5)$ \\
\hline JO-1 & $4(8.6)$ & $1(5.8)$ & $3(10.7)$ & $3(60)$ & $2(18.1)$ & 0 & $3(23)$ & $4(36.3)$ & $5(10.4)$ \\
\hline $\begin{array}{l}\text { NON JO-I ARS } \\
\text { (PL-7) }\end{array}$ & $1(2.1)$ & 0 & $2(7.1)$ & 0 & $2(18.1)$ & 0 & 0 & $1(9)$ & $2(4.1)$ \\
\hline SRP & $2(4.3)$ & 0 & 0 & 0 & 0 & 0 & 0 & $1(9)$ & $2(4.1)$ \\
\hline MDA-5 & 0 & 0 & $1(3.5)$ & $1(20)$ & $1(9)$ & $1(50)$ & $1(7.6)$ & 0 & $1(2)$ \\
\hline NXP2 & $1(2.1)$ & $1(5.8)$ & $1(3.5)$ & 0 & 0 & 0 & 0 & 0 & $1(2)$ \\
\hline TIF1 $\gamma$ & $1(2.1)$ & 0 & 0 & 0 & 0 & 0 & 0 & $1(9)$ & $1(2)$ \\
\hline SAE1 & 0 & 0 & 0 & 0 & 0 & 0 & 0 & 0 & 0 \\
\hline SAE2 & 0 & 0 & 0 & 0 & 0 & 0 & 0 & 0 & 0 \\
\hline \multicolumn{10}{|c|}{ Myositis Associated Antibodies } \\
\hline RO52 & $14(30.4)$ & $4(23.5)$ & $10(35.7)$ & $4(80)$ & $6(54.5)$ & $1(50)$ & $3(23)$ & $5(45.4)$ & $\begin{array}{c}16 \\
(33.3)\end{array}$ \\
\hline PM SCL & $1(2.1)$ & 0 & 0 & 0 & 0 & 0 & 0 & $1(9)$ & $1(2)$ \\
\hline RNP & $2(4.3)$ & $1(5.8)$ & $1(3.5)$ & 0 & $2(18.1)$ & $1(50)$ & $2(15.3)$ & $2(18.1)$ & $2(4.1)$ \\
\hline $\mathrm{Ku}$ & 0 & 0 & 0 & 0 & 0 & 0 & 0 & 0 & 0 \\
\hline
\end{tabular}

